\title{
Strategi Implementasi Adaptive Neuro Fuzzy Inference System (ANFIS) pada Kendali Motor Induksi 3 Fase Metode Vektor-Tidak Langsung
}

\section{HANIF HASYIER FAKHRUDDIN ${ }^{1}$, HANDRI TOAR ${ }^{2}$, ERA PURWANTO ${ }^{3}$, HARY OKTAVIANTO4, GAMAR BASUKI5, RADEN AKBAR NUR APRIYANTO6, ABDILLAH AZIZ MUNTASHIR ${ }^{7}$}

1,3,4,5,6,7Departemen Teknik Elektro, Politeknik Elektronika Negeri Surabaya

2Jurusan Teknik Elektro, Politeknik Negeri Batam

Email: hanifhasyier@gmail.com

Received 30 Maret 2021 | Revised 24 April 2021 | Accepted 25 Mei 2021

\begin{abstract}
ABSTRAK
Kendali vektor merupakan solusi terbaik dalam kendali motor induksi untuk meningkatkan karakter dinamis dan efisiensinya. Pada penelitian ini, sebuah kendali kecepatan PID dipadukan dengan Adaptive Neuro Fuzzy Inference System (ANFIS) untuk meningkatkan keandalan pada berbagai kecepatan acuan. Metode cerdas Particle Swarm Optimization (PSO) digunakan untuk optimasi dataset ANFIS. Pengujian keandalan dilakukan dengan membandingkan PID konvensional dengan PID-ANFIS pada motor induksi 3 fase berdaya 2HP. Validasi penelitian dilakukan melalui simulasi di platform LabView. PID-ANFIS membuktikan hasil yang jauh lebih baik dari kendali PID konvensional pada berbagai kecepatan acuan. Pemilihan rise time tercepat sebagai fungsi fitness menghasilkan kendali yang memiliki dead time dan rise time $1.5 x$ lebih cepat. PID-ANFIS berhasil menghilangkan undershoot dan osilasi steady state ketika uji kecepatan tinggi.
\end{abstract}

Kata kunci: Kendali Vektor, Adaptive Neuro Fuzzy Inference System, Particle Swarm Optimization, LabView

\begin{abstract}
Vector control is the best solution in induction motor control to enhance its dynamic character and efficiency. In this research, a PID speed controller is combined with the Adaptive Neuro-Fuzzy Inference System (ANFIS) to enhance reliability at various reference speeds. The intelligent method Particle Swarm Optimization (PSO) is used to optimize the ANFIS dataset. Reliability testing is done by comparing conventional PID with PID-ANFIS on a 2HP 3-phase induction motor. The research validation was carried out through a simulation on the LabView platform. The PID-ANFIS proved significantly better results than conventional PID control at a wide range of reference speeds. Selection of the fastest rise time as a fitness function results in a control that has a dead time and a rise time of $1.5 x$ faster. PID-ANFIS successfully negates undershoot and steadystate oscillations during high-speed tests.
\end{abstract}

Keywords: Vector Control, Adaptive Neuro Fuzzy Inference System, Particle Swarm Optimization, LabView 


\section{PENDAhUlUAN}

Di berbagai industri, motor induksi berperan sangat besar sehingga diproduksi dalam jumlah besar sesuai permintaan pasar. Lebih dari setengah energi listrik di negara maju digunakan sebagai konsumsi motor listrik industri, di mana lebih dari $90 \%$ adalah motor induksi. Motor induksi saat ini merupakan mesin AC yang paling banyak digunakan karena keunggulan di segi harga, keandalan, dan kinerjanya (Rind, dkk, 2017). Selama ini, motor induksi hanya digunakan pada kecepatan tetap untuk aplikasi tertentu. Dalam beberapa dekade terakhir, perkembangan pesat piranti elektronik daya dan teknologi konverter memungkinkan kendali kecepatan yang efisien dengan memvariasikan frekuensi catu daya, sehingga memungkinkan sebagai kendali motor induksi untuk kecepatan bervariasi.

Mesin industri memerlukan kendali kecepatan kinerja tinggi. Dalam sistem penggerak kinerja tinggi, kecepatan motor haruslah mengikuti acuan yang ditentukan walaupun terdapat gangguan beban dan faktor lain. Untuk mencapai kinerja tinggi, kendali field-oriented digunakan untuk penggerak motor induksi. Dalam teori kendali vektor, pengaturan torsi dan flux motor induksi dilakukan secara terpisah seperti motor DC eksitasi terpisah (Menghal \& Laxmi, 2016)(Ridwan, dkk, 2019). Pengendalian kecepatan pada motor induksi dengan respon transien dan tunak yang baik menjadi kriteria utama dalam perancangan sebuah kontroler.

Beberapa riset tentang kendali kecepatan pada metode kendali vektor terus dikembangkan untuk meningkatkan keandalan ketika ada gangguan beban, frekuensi, suhu, dan faktor lainnya. Kendali konvensional sudah tidak dapat mengatasi gangguan tersebut maka banyak beralih ke metode cerdas untuk dapat mengatasi masalah ini. Penelitian metode cerdas pada kendali motor induksi meliputi fuzzy logic, fuzzy gain-scheduling, algoritma genetik, particle swarm optimization, Sliding-mode, dan lain-lain (Ferdiansyah, dkk, 2016)(Hannan, dkk, 2018).

Di lain sisi, metode cerdas yang semakin rumit membuat tidak memungkinkan untuk dibenamkan pada mikrokontrol. Fuzzy logic adalah metode cerdas yang sesuai dengan mikrokontrol yang terjangkau dengan kinerja bagus. Masalah utama dalam sebuah fuzzy logic adalah desain membership dan rule (Chao, dkk, 2019)(Simon \& Geetha, 2013). Dalam bidang clustering, seorang ahli dapat dengan mudah membantu desain membership dan rule, akan tetapi dalam bidang kontrol tidak ada acuan baku hasil luaran fuzzy sehingga menjadi tantangan bagi seorang ahli. Metode cerdas jaringan saraf tiruan dalam 20 tahun terakhir telah dikembangkan untuk melakukan pembelajaran terhadap fuzzy logic, sehingga menghasilkan metode Adaptive Neuro Fuzzy Inference System (ANFIS). Penggunaan ANFIS menggabungkan keuntungan yang ditawarkan oleh logika fuzzy (FLC) dan Jaringan Saraf Tiruan (JST). JST melatih Fuzzy Inference System (FIS) sesuai dengan datasetpembelajaran sehingga terbentuk membership dan rule fuzzy yang paling sesuai (Hussain \& Bazaz, 2014)(Sathishkumar \& Parthasarathy, 2017).

Penelitian ANFIS sebagai kendali kecepatan telah dilakukan oleh Sathishkumar dalam jurnalnya, sedangkan penelitian Fuzzy Gain-Scheduling dengan desain rule Fuzzy secara konvensional telah dilakukan oleh Ferdiansyah dalam jurnalnya (Ferdiansyah, dkk, 2016)(Sathishkumar \& Parthasarathy, 2017). Dalam penelitian ini, pegontrol kecepatan berbasis PID gain-scheduling dengan penala otomatis Artificial Neural-Fuzzy Inference System sebagai strategi baru penggerak motor induksi menggunakan metode kendali vektor-tidak langsung (indirect-vector contro). Parameter-parameter PID sebagai dataset akan dioptimasi menggunakan PSO gara datasetyang didapatkan merupakan dataset yang terbaik. Selain itu, 
PSO memiliki kemampuan konvergensi solusi yang lebih cepat sehingga bisa mempercepat proses pengumpulan dataset. Desain penelitian dilakukan pada platform LabView sehingga mudah untuk ditanamkan pada perangkat keras produk National Instrument. Penelitian ini bertujuan untuk memperkaya area riset LabView di Indonesia. Secara khusus, tujuan penelitian ini adalah untuk memvalidasi performa strategi implementasi ANFIS pada kendali kecepatan motor induksi 3 fase.

\section{METODOLOGI PENELITIAN}

Pengendali pada motor induksi merupakan metode untuk mempertahankan kecepatan sesuai dengan acuan, hal yang menjadi gangguan bisa dari beban, suhu, frekuensi, dan lain-lain. Piranti elektonik daya yang berupa inverter menyesuaikan tegangan dan frekuensinya untuk meredam gangguan. Piranti mikrokontrol merupakan otak dari inverter yang bertugas membaca masukan sensor yang ada, kemudian mengeluarkan sinyal control untuk kendali inverter. Platform LabView mendukung piranti keras produk National Instrumen sehingga dari simulasi bisa dengan cepat dibenamkan pada mikrokontrol (Salim \& Ohri, 2015). Penelitian ini akan difokuskan dalam perbandingan kendali kecepatan PID konvensional dengan PIDANFIS pada kendali vektor motor induksi. Pengujian penelitian ini dilakukan simulasi pada LabView dengan parameter motor simulasi disesuaikan dengan parameter motor asli $2 \mathrm{HP}$. Pengujian dilakukan dengan beban nol dan beban penuh (9Nm).

\subsection{Kendali Vektor Indirect-Field Oriented Control(IFOC)}

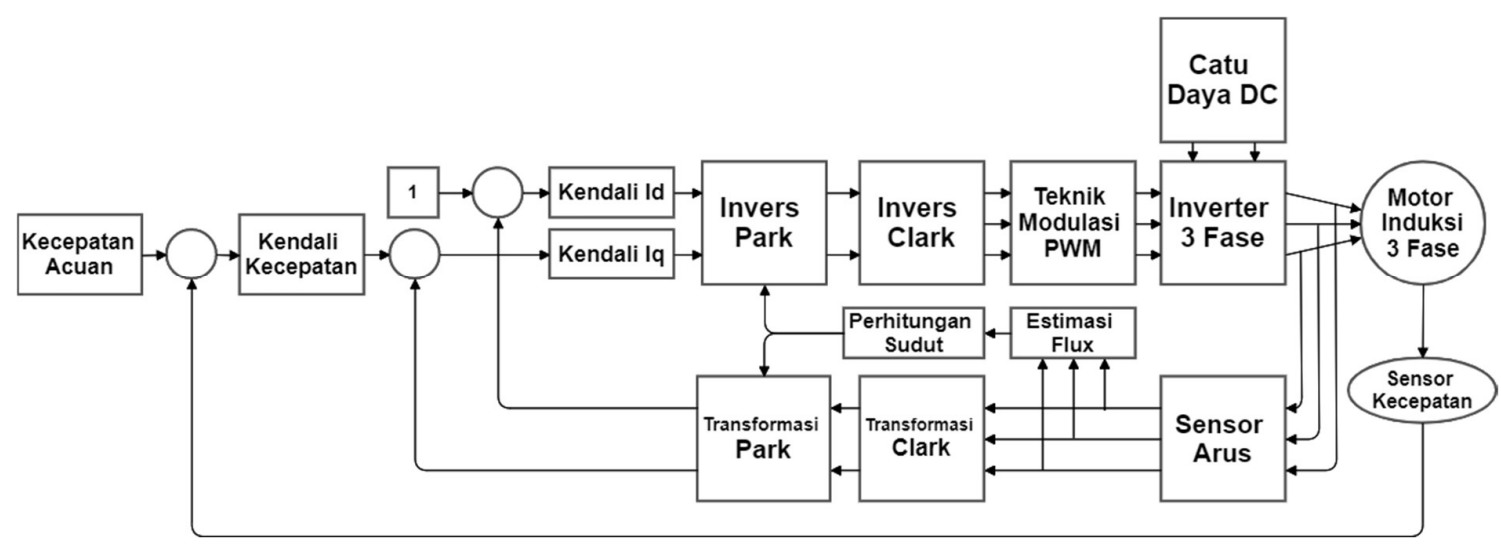

Gambar 1. Diagram Blok Kendali Indirect-Field Oriented Control

Kendali vektor merupakan kendali performa tinggi pada mesin AC dimana flux dan torsi bisa dikendalikan secara terpisah semudah DC penguat terpisah. Kendali vektor akrab dengan transformasi Clark dan Park, fungsi transformasi ini adalah mengubah analisis 3 fase menjadi 2 fase. Fase tersebut adalah fase $\mathrm{d}$ dan $\mathrm{q}$, karena yang ditransformasikan adalah arus maka disebut $I_{d}$ dan $I_{q} . I_{d}$ erat hubungannya dengan kendali flux, sedangkan Iq berhubungan dengan kendali torsi (Toar, dkk, 2020). Salah satu jenis kendali vektor yang paling popular adalah Field-Oriented Control, Gambar 1 merupakan diagram blok dari metode Indirect-Field Oriented Control yang akan dibahas lebih lanjut pada bagian ini. Persamaan (1) dan (2) merupakan rumus transformasi Clark (1) dan Park (2).

$$
\begin{aligned}
i_{s \alpha} & =i_{a} \\
i_{s \beta} & =\frac{1}{\sqrt{3}} i_{a}+\frac{2}{\sqrt{3}} i_{b}
\end{aligned}
$$


Strategi Implementasi Adaptive Neuro Fuzzy Inference System (ANFIS) pada Kendali Motor Induksi 3

$$
\begin{aligned}
& i_{d s}=i_{\alpha \cdot} \cdot \cos (\theta)+i_{\beta} \cdot \sin (\theta) \\
& i_{q s}=-i_{\alpha} \cdot \sin (\theta)+i_{\beta} \cdot \cos (\theta)
\end{aligned}
$$

Jika dituliskan pada pemrograman LabView, Gambar 2 (a) merupakan program transformasi Clark dan (b) merupakan program transformasi Park.

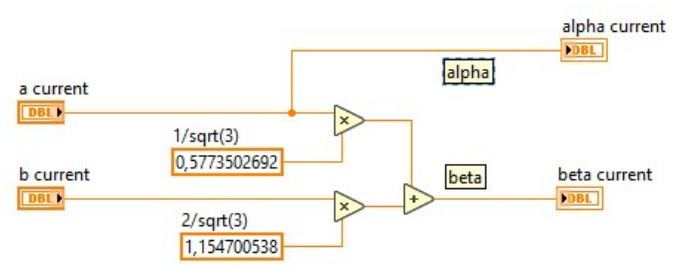

(a)

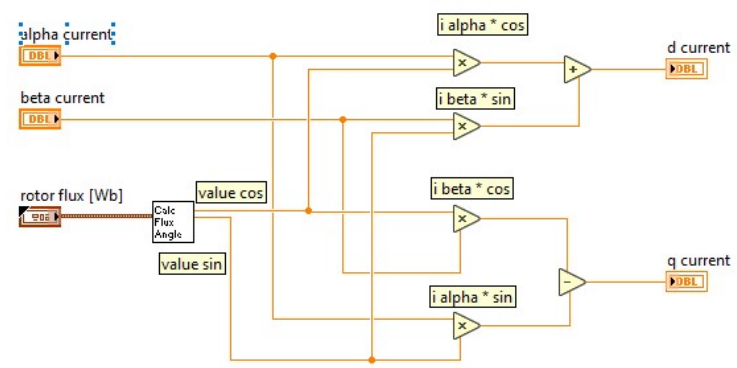

(b)

\section{Gambar 2. Transformasi Clark (a) dan Transformasi Park (b)}

Untuk mengubah menjadi 3 sinyal kontrol inverter, maka sistem 2 sumbu d-q perlu dilakukan invers transformasi Clark dan Park. Persamaan invers transformasi dituliskan pada Persamaan (3) untuk invers Clark dan (4) untuk invers Park.

$$
\begin{gathered}
i_{s \alpha}=i_{d s} \cdot \cos (\theta)-i_{q s} \cdot \sin (\theta) \\
i_{s \beta}=i_{d s} \cdot \sin (\theta)+i_{q s} \cdot \cos (\theta) \\
i_{a}=i_{\alpha} \\
i_{b}=-\frac{1}{2} i_{\alpha}+\frac{\sqrt{3}}{2} i_{\beta} \\
i_{c}=-\frac{1}{2} i_{\alpha}-\frac{\sqrt{3}}{2} i_{\beta}
\end{gathered}
$$

Jika dituliskan pada pemrograman LabView, Gambar 3 (a) merupakan program invers transformasi Clark dan (b) merupakan program invers transformasi Park.

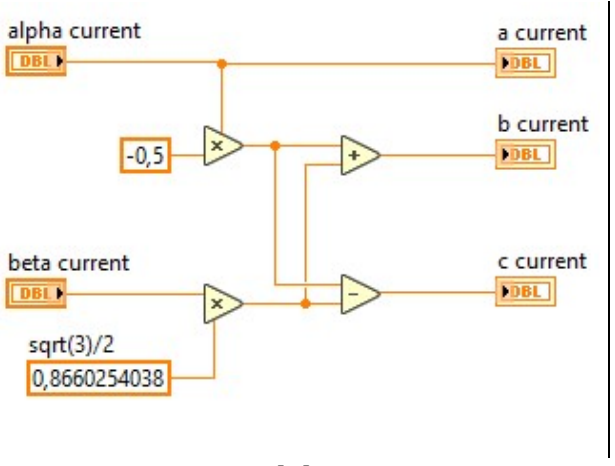

(a)

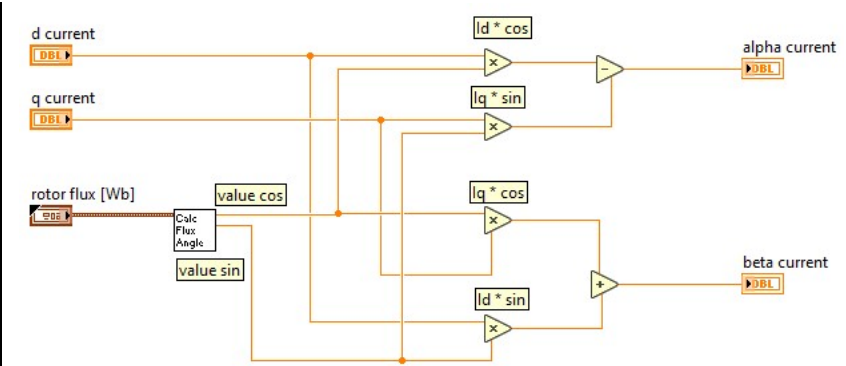

(b)

Gambar 3. Invers Transformasi Clark (a) dan Invers Transformasi Park (b) 
Nilai estimasi posisi motor pada metode vektor tidak langsung merupakan integral dari nilai kecepatan. Sedangkan untuk metode vektor langsung nilai posisi rotor didapat dari sensor hall magnet yang dipasang di celah udara (air gap). Metode tidak langsung lebih mudah diterapkan mengingat konstruksi celah udara motor induksi yang sangat sempit. Penentuan posisi rotor juga dapat diestimasi dari vektor flux atau biasa disebut sebagai rotor flux estimator. Nilai estimasi ini merupakan perhitungan vektor dari arus 3 fase kemudian didapatkan nilai estimasi flux alpha dan flux betha, nilai magnitude dari sudut alpha dan betha inilah yang menghasilkan nilai arctan posisi rotor. Persamaan (5) adalah persamaan dari rotor flux estimator dan Persamaan (6) adalah persamaan penentuan posisi rotor dalam metode vektor tidak langsung bedasarkan posisi estimasi flux.

$$
\begin{gathered}
\lambda_{r \alpha}=\operatorname{lpf}\left\{\frac{I_{\alpha} L_{m} R_{r}}{L_{m}+L_{l}}-\frac{\omega_{r} p}{2 \lambda_{r \beta}}, \frac{R_{r}}{L_{m}+L_{l}}\right\} \\
\lambda_{r \beta}=\operatorname{lpf}\left\{\frac{I_{\beta} L_{m} R_{r}}{L_{m}+L_{l}}-\frac{\omega_{r} p}{2 \lambda_{r \alpha}}, \frac{R_{r}}{L_{m}+L_{l}}\right\} \\
\cos \theta=\frac{\lambda_{r \alpha}}{\sqrt{\lambda_{r \alpha}^{2}+\lambda_{r \beta}^{2}}} \\
\sin \theta=\frac{\lambda_{r \beta}}{\sqrt{\lambda_{r \alpha}^{2}+\lambda_{r \beta}^{2}}}
\end{gathered}
$$

Persamaan (6) jika dituliskan dalam program LabView maka akan seperti Gambar 4.

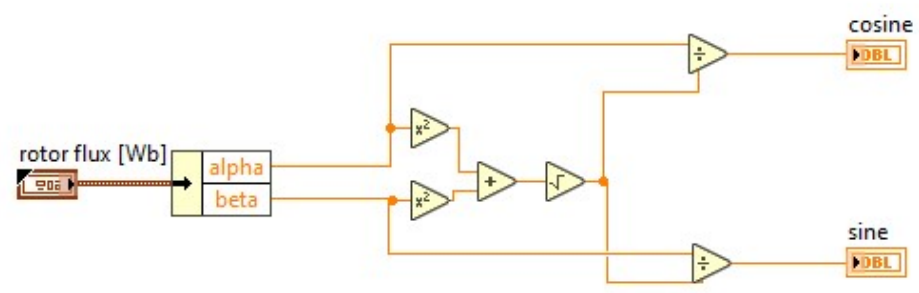

Gambar 4. Perhitungan Sudut Flux Rotor

Dengan nilai low pass filter seperti Persamaan (7).

$$
\operatorname{lpf}=\frac{1}{\frac{R_{r}}{L_{m}+L_{r}} s+1}
$$

Dimana $\lambda_{r \alpha}$ dan $\lambda_{r \beta}$ masing-masing adalah estimasi flux rotor alpha dan betha; $I_{\alpha}$ dan $I_{\beta}$ masing-masing adalah arus alpha dan arus betha hasil invers transformasi Clark; $L_{r}, L_{m}$ dan $L_{l}$ masing-masing dalah induktansi rotor, induktansi bersama (mutual) dan induktansi bocor (leakage); $\omega_{r}$ adalah kecepatan putar rotor; $p$ adalah jumlah pole; $R_{r}$ adalah resistansi pada rotor. Untuk membandingkan kinerja kendali kecepatan, maka parameter $I_{d}$ dan $I_{q}$ regulator dijadikan nilai tetap. Hal yang diamati pada kinerja kendali kecepatan meliputi respon transien dan kondisi tunak pada kecepatan dan beban yang berubah-ubah.

\subsection{Optimasi dataset ANFIS menggunakan Particle Swarm Optimization (PSO)}

Pada tahun 1995, Ebehart dan kawan-kawan menemukan teknik komputasi terbaru yang terinspirasi dari cara burung berkelompok. Teknik ini kemudian diberi nama Particle Swarm Optimization (PSO), dimana posisi dari banyak partikel dijadikan sebagai calon solusi 
(candidate solution) suatu masalah optimisasi. Dalam PSO terdapat fungsi fitness, fungsi fitness adalah parameter yang sesuai untuk menentukan suatu optimasi dari sebuah masalah. Pada penelitian tentang kendali kecepatan, fungsi fitness bisa diambil dari deadtime, risetime atau parameter lain yang berhubungan dengan karakter dinamis.

PSO identik dengan populasi dan yang terbaik dalam populasi tersebut dinamakan local best, para local best dari banyak populasi kemudian diambil lagi yang terbaik sebagai global best. Faktor yang sangat mempengaruhi PSO dan kecepatan (velocity) dan posisi kandidat. Persamaan (8) dan (9) masing-masing merupakan rumus untuk memperbarui kecepatan dan posisi kandidat (Fakhruddin, dkk, 2020).

$$
\begin{gathered}
V_{i}^{d}(t+1)=w V_{i}^{d}(t)+c_{1} r_{1}\left(P_{i}^{d}(t)-X_{i}^{d}(t)\right)+c_{2} r_{2}\left(P_{i}^{d}(t)-X_{i}^{d}(t)\right) \\
X_{i}^{d}(t+1)=X_{i}^{d}(t)+V_{i}^{d}(t+1)
\end{gathered}
$$

Dimana $r_{1}$ dan $r_{2}$ adalah nilai acak 0 sampai $1 ; V$ adalah kecepatan individu $i$ pada iterasi $d$; $c_{1}$ dan $c_{2}$ adalah laju perubahan sosial; $t$ adalah iterasi saat ini; $w$ adalah berat inersia; Dan $X$ adalah faktor posisi.

Gambar 5 merupakan alur mendapatkan dataset yang telah dioptimasi PSO untuk digunakan pada kendali PID-ANFIS. Langkah pertama adalah mencari konvergen nilai parameter PID, seperti yang telah dijelaskan bahwa faktor posisi merupakan unsur penting dalam PSO.

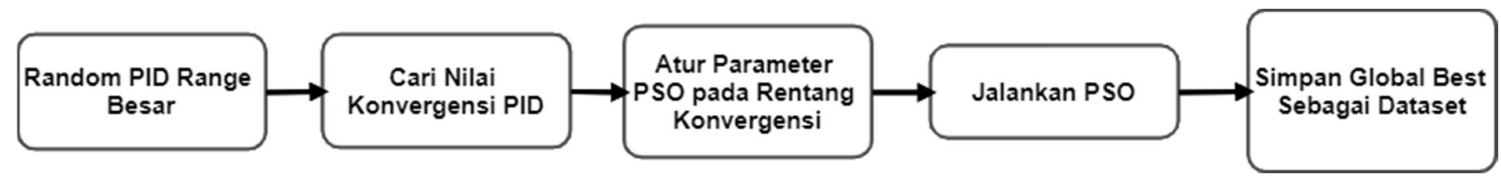

Gambar 5. Alur Optimasi Parameter PID dengan PSO pada LabView

Keuntungan mencari nilai konvergensi di awal adalah meminimalkan kemungkinan terjebak dalam local best. Hal yang munkin dilakukan adalah melakukan konvergensi berulang-ulang untuk memperbesar peluang mendapatkan global best. Gambar 6 adalah fitur optimasi menggunakan PSO yang digunakan pada penelitian ini.

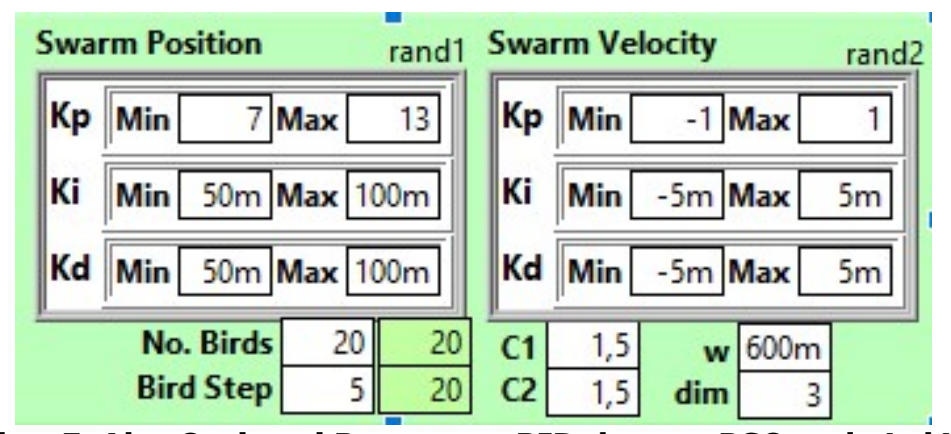

Gambar 5. Alur Optimasi Parameter PID dengan PSO pada LabView

Penelitian ini menjadikan nilai risetime tercepat sebagai fungsi fitness, agar mendapat hasil respon kecepatan cepat dalam menyesuaikan lintasan acuan. Nilai-nilai dataset berupa parameter Kp, Ki dan Kd yang didapatkan dari global best PSO pada tiap kecepatan dan beban berbeda. 


\subsection{Desain PID-ANFIS}

Berbagai macam kendali cerdas seperti Fuzzy, Neural Network, dan lain-lain telah teruji dapat meningkatkan kemampuan kendali vektor dengan kepresisian tinggi. Fuzzy Logic adalah kecerdasan buatan yang bedasarkan penalaran kecerdasan manusia, dimana masukan dan luaran tidak harus presisi tetapi hasilnya bisa diterima sesuai rule Fuzzy. Neural Network merupakan sekumpulan masukan (input) dikali bobot. Bobot ini dibelajari untuk menghasilkan luaran (output) sesuai harapan. Pada skema ANFIS, tiap input dituliskan dalam 1 node. Kemudian, tiap node input terhubung hidden layer 1 yang merupakan jumlah membership tiap input. Pada hidden layer 2 , jumlah node merupakan jumlah ruleyang tersedia. Selanjutnya hidden layer 3 merupakan lapisan seperti layer 2, akan tetapi lapisan ini bersifat adaptif karena nilai bobotnya diperbarui ketika ada propagasi balik. Output adalah node terakhir setelah layer 3. Terdapat 2 metode untuk learning ANFIS, yaitu umpan maju dan propagasi balik. Nilai-nilai bobot yang telah diperbarui setelah proses belajar menjadi faktor utama dalam bergesernya membership input dan perubahan rule pada ANFIS (Rajab, 2019)(Sanjeevikumar, dkk, 2015).

Faktor sistem benam yang dipilih merupakan pertimbangan terbesar ketika penerapan kendali cerdas di lapangan. Kendali Fuzzy merupakan kendali cerdas yang masih bisa dibenamkan pada sistem embedded harga murah. Kendali cerdas yang lebih rumit memerlukan sistem dengan komputasi sangat cepat sehingga harga yang dikeluarkan lebih tinggi (Qudsi, dkk, 2018). ANFIS dalam implementasinya merupakan sebuah Fuzzy logic, tetapi rule dan membeship-nya telah dibelajarkan oleh Neuro Network.

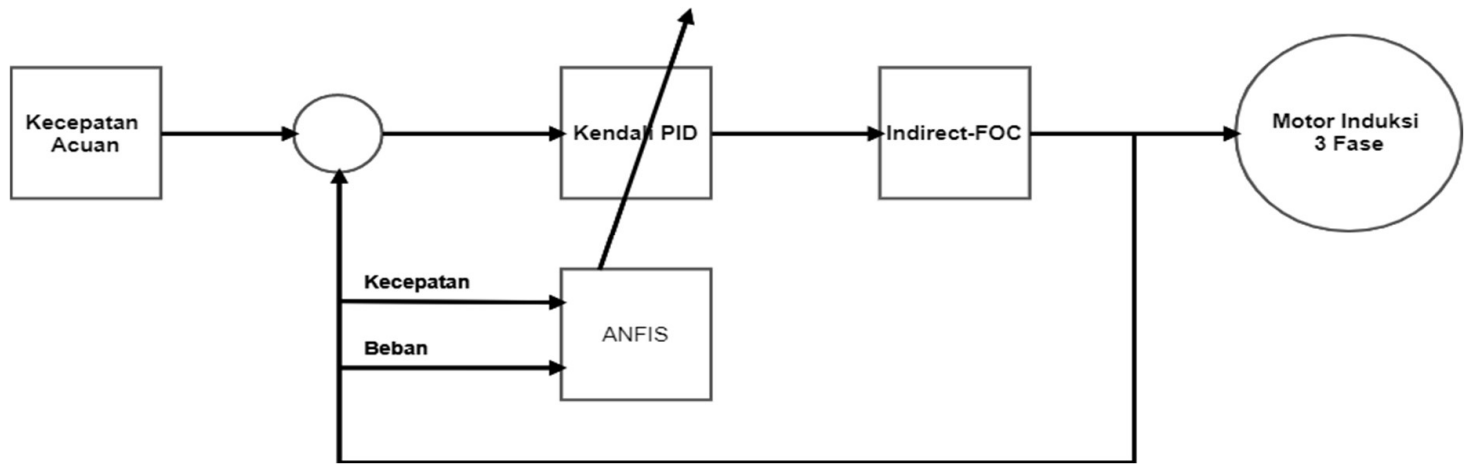

Gambar 6. Diagram Sistem Kendali PID-ANFIS

Penelitian ini menggunakan ANFIS sebagai penala otomatis parameter PID, Gambar 6 merupakan diagram blok sistem penelitian. Masukan ANFIS adalah beban dan kecepatan. Layerke-2 terdiri dari 10 hidden node, dengan masing-masing inputterhubung dengan 5 node membership berbentuk fungsi trapesium. Layer ke- 3 terdiri dari rule sistem inferensi fuzzy $5 \times 5$ sehingga 25 node. Lapisan berikutnya adalah fungsi keanggotaan luaran yang berjumlah 25 fungsi sigmoid karena fuzzy yang dipakai adalah tipe Sugeno. Lapisan keluaran akhirnya memproses sinyal berbobot melalui fungsi aktivasi dan menghasilkan parameter PID. Gambar 7 merupakan contoh struktur ANFIS untuk penalaan parameter Kp. 


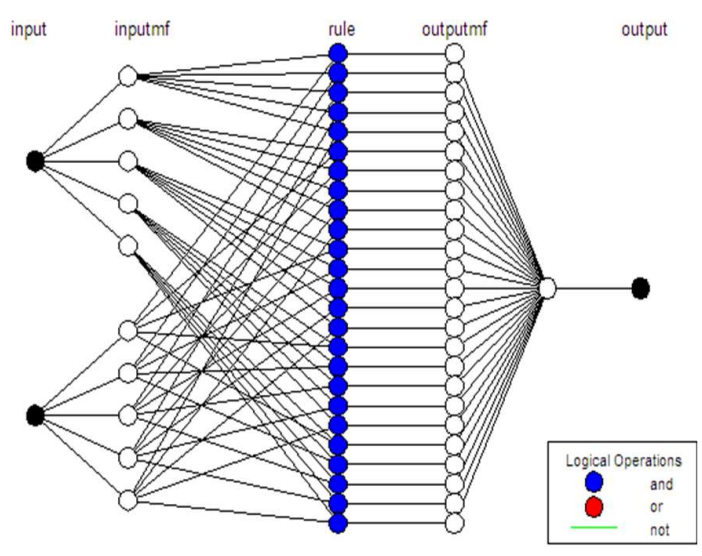

(a)

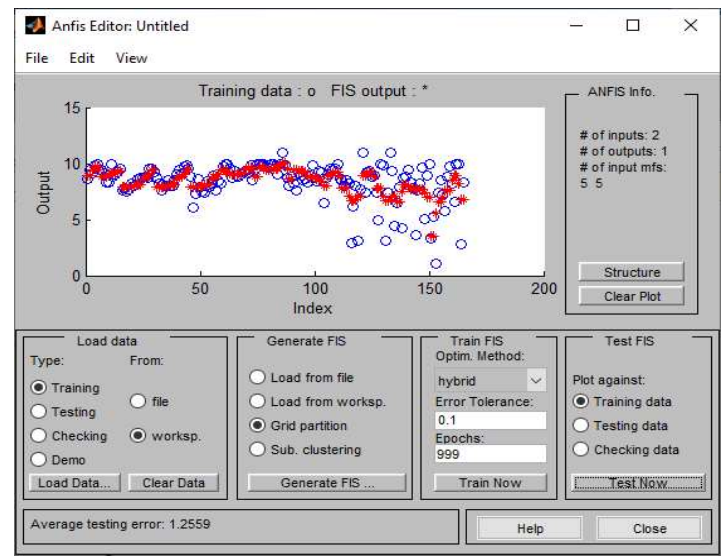

(b)

Gambar 7. Struktur ANFIS (a) dan Hasil Uji Hasil Belajar ANFIS (b)

Dengan proses belajar 999 iterasi, didapatkan hasil error sekitar 1,76\% dan perubahan parameter trapesium membership. Tabel 1 merupakan perubahan parameter trapesium untuk membership input kecepatan hasil dari ANFIS. Gambar 7 (b) merupakan uji ANFIS terhadap dataset yang digunakan sebagai dasar dari pembelajaran ANFIS.

Tabel 1. Membership-Input Fuzzy Sebelum dan Sesudah Proses Belajar

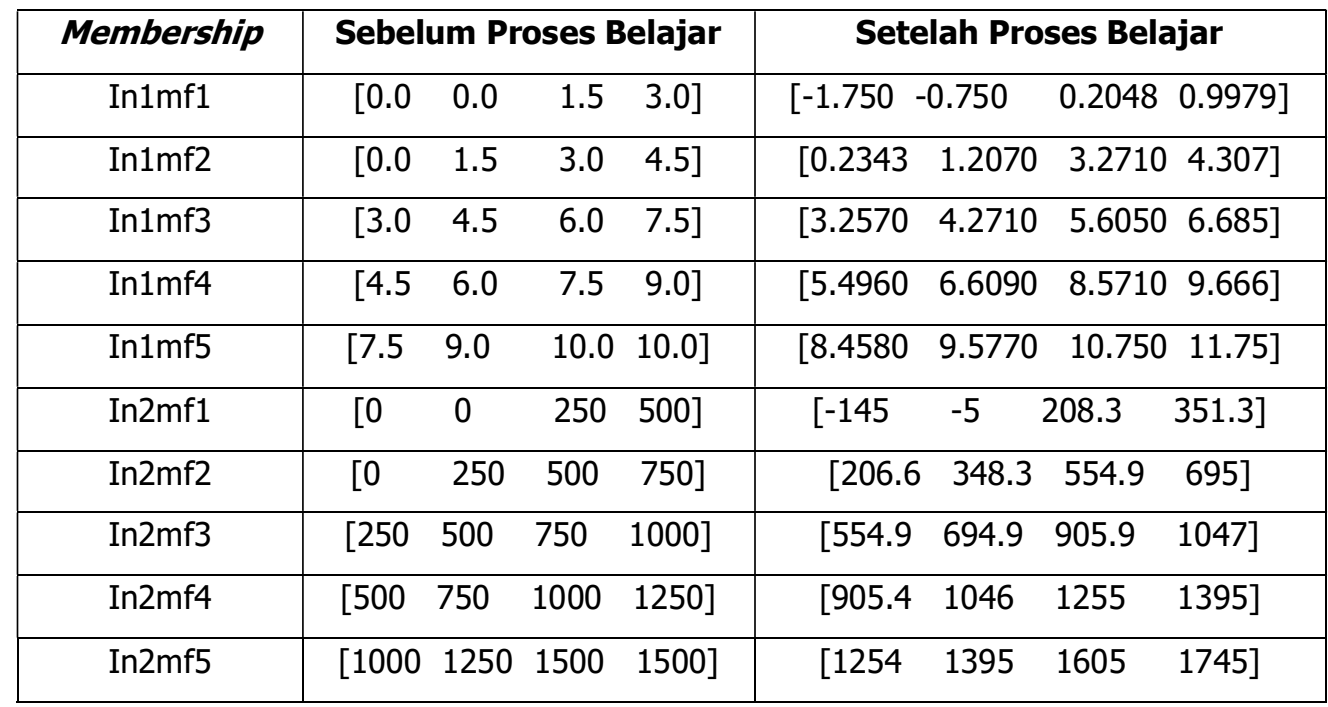

Parameter Fuzzy hasil pembelajaran ANFIS selanjutnya digunakan pada platform LabView. Penelitian ini menggunakan rangkaian simulasi LabView seperti pada Gambar 8. Terdapat 3 buah Fuzzy yang masing-masing untuk menala parameter PID. 


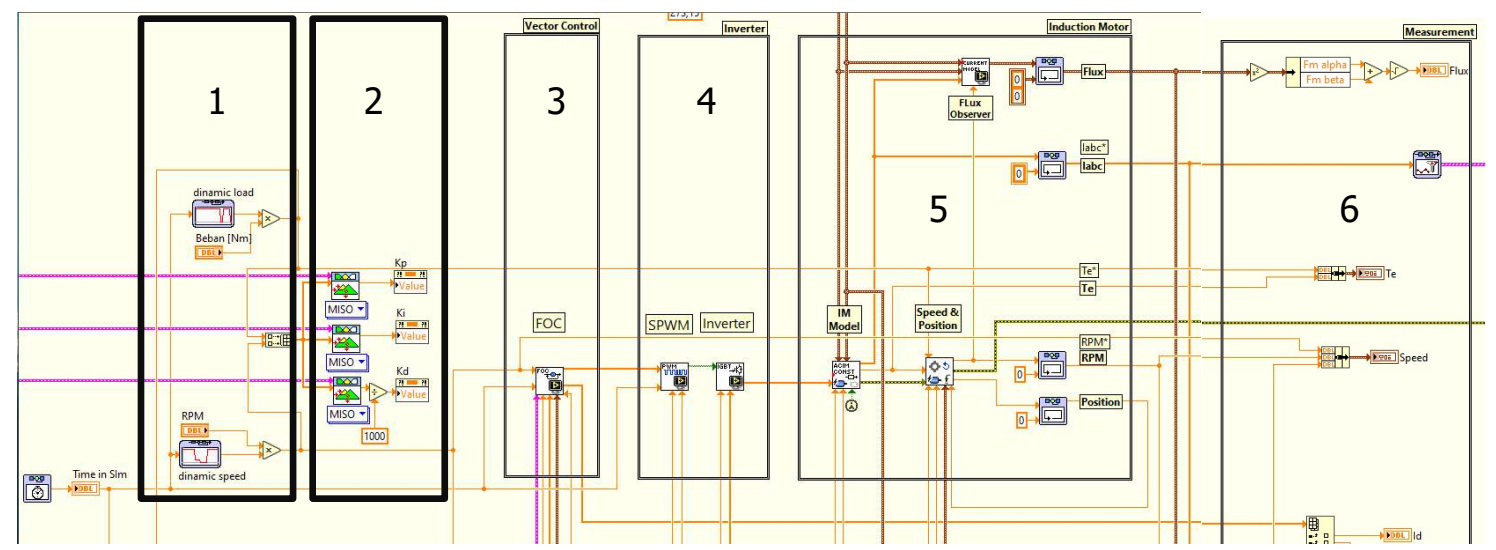

Gambar 8. Rangkaian Pengujian pada LabView

Kotak ke-1 pada Gambar 8 adalah penghasil kecepatan dan beban berubah (dinamis). Kotak ke-2 berisi Fuzzy Logic hasil pembelajaran ANFIS untuk menala parameter PID. Kotak ke-3 adalah diagram blok Indirect-Field Oriented Control pada penelitian. Kotak ke-4 adalah pembangkit sinyal SPWM dan Inverter 3 fase. Kotak ke-5 adalah motor induksi 3 fase. Kotak ke-6 adalah monitoring kecepatan, arus, torsi, dan lain-lain yang ditampilkan pada panel muka LabView seperti pada Gambar 10. Pada kotak ke-2, nilai parameter Kd perlu dibagi dengan 1000 untuk menjadikan nilainya dalam mili.

\section{PENGUJIAN DAN ANALISIS}

Untuk mengevaluasi kendali PID-ANFIS sebagai kendali kecepatan pada kendali vektor-tidak langsung, dilakukan pengujian pada platform LabView dengan motor berdaya 10HP dan teknik modulasi SPWM. Parameter pengujian dan spesifikasi motor induksi 3 fase yang digunakan tertera pada tabel 2. Parameter PID konvensional pembanding diambil dari nilai tengah dari sebaran dataset ANFIS, yaitu $\mathrm{Kp}=9, \mathrm{Ki}=5$, dan $\mathrm{Kd}=4.5 \mathrm{~m}$. Studi evaluasi diamati dalam 2 keadaan yaitu beban tetap dan beban berubah. PID konvensional dibandingkan dengan PIDANFIS kemudian diamati peforma dinamis meliputi risetime (Tr), settling time (TS), steady state, undershoot, error steady state(ESS), dan waktu recovery ketika ada gangguan.

Tabel 2. Parameter Motor Induksi yang Digunakan

\begin{tabular}{|c|c|c|c|c|c|c|c|}
\hline No & Parameter & Nilai & Satuan & No & Parameter & Nilai & Satuan \\
\hline 1. & Tahanan stator & 0.896 & $\Omega$ & 6. & Daya nominal & 2 & HP \\
\hline 2. & Tahanan rotor & 1.82 & $\Omega$ & 7. & Tegangan nominal & 380 & Volt \\
\hline 3. & Induktansi stator & 1.94 & $m H$ & 8. & Frekuensi & 50 & $\mathrm{~Hz}$ \\
\hline 4. & Induktansi rotor & 2.45 & $m H$ & 9. & Jumlah kutub & 4 & unit \\
\hline 5. & Induktansi bersama & 46.2 & $m H$ & 10. & Kecepatan nominal & 1435 & Rpm \\
\hline
\end{tabular}

\subsection{Uji Beban Nol}

Pengujian tanpa beban dilakukan dengan kecepatan acuan 100rpm (kecepatan rendah), 750rpm( kecepatan sedang), dan 1500rpm (kecepatan tinggi). Pada pengujian beban nol, overshoot dan undershoot dari PID maupun dari PID-ANFIS bernilai 0\%. Error steady state sama untuk keduanya yaitu 0\%. Ketika kecepatan 1500rpm dan beban 0Nm, ANFIS secara adaptif menala PID menjadi $\mathrm{kp}=9.32, \mathrm{Ki}=5.19$, dan $\mathrm{Kd}=8.12 \mathrm{~m}$. Risetime PID konvensional sedikit lebih lambat dari pada PID-ANFIS di berbagai kecepatan acuan. Risetime mulai terlihat 
berbeda ketika kecepatan tinggi 1500rpm, risetime kendali PID konvensional sebesar 4.8ms dan kendali PID-ANFIS sebesar $4.2 \mathrm{~ms}$. Tabel 3 merupakan perbandingan karakter dinamis keseluruhan pada pengujian beban nol.

Tabel 3. Perbandingan Karakter Dinamis pada Uji Beban Nol

\begin{tabular}{|c|c|c|c|c|c|c|c|}
\hline \multirow[b]{2}{*}{ Parameter } & \multicolumn{2}{|c|}{ 100rpm } & \multicolumn{2}{|c|}{ 750rpm } & \multicolumn{2}{|c|}{ 1500rpm } & \multirow[b]{2}{*}{ Satuan } \\
\hline & $\begin{array}{l}\text { Kendali } \\
\text { ANFIS }\end{array}$ & $\begin{array}{l}\text { Kendali } \\
\text { PID }\end{array}$ & $\begin{array}{l}\text { Kendali } \\
\text { ANFIS }\end{array}$ & $\begin{array}{c}\text { Kendali } \\
\text { PID }\end{array}$ & $\begin{array}{l}\text { Kendali } \\
\text { ANFIS }\end{array}$ & $\begin{array}{c}\text { Kendali } \\
\text { PID }\end{array}$ & \\
\hline Dead time & 0.4 & 0.4 & 0.6 & 0.6 & 0.8 & 0.8 & $\mathrm{~ms}$ \\
\hline Rise Time & 1.9 & 2.0 & 3.5 & 3.6 & 4.2 & 4.8 & $\mathrm{~ms}$ \\
\hline Overshoot & 0.0 & 0.0 & 0.0 & 0.0 & 0.0 & 0.0 & $\%$ \\
\hline Undershoot & 0.0 & 0.0 & 0.0 & 0.0 & 0.0 & 0.0 & $\%$ \\
\hline Error Steady & 0.0 & 0.0 & 0.0 & 0.0 & 0.0 & 0.0 & $\%$ \\
\hline Undershoot & 0.0 & 0.0 & 0.0 & 0.0 & 0.0 & 0.0 & $\%$ \\
\hline Overshoot & 0.0 & 0.0 & 0.0 & 0.0 & 0.0 & 0.0 & $\%$ \\
\hline
\end{tabular}

Kesimpulan sementara dari pengujian ini adalah kendali PID-ANFIS lebih unggul dari kendali PID saat uji beban nol pada aspek risetime, sesuai dengan fungsi fitness PSO yang mencari dataset risetime tercepat. PID-ANFIS pada pengujian ini lebih cepat dalam merespon perubahan kecepatan acuan. Gambar 9 merupakan hasil pengujian pada kecepatan 1500rpm, PID konvensional bewarna merah dan PID-ANFIS bewarna hijau.

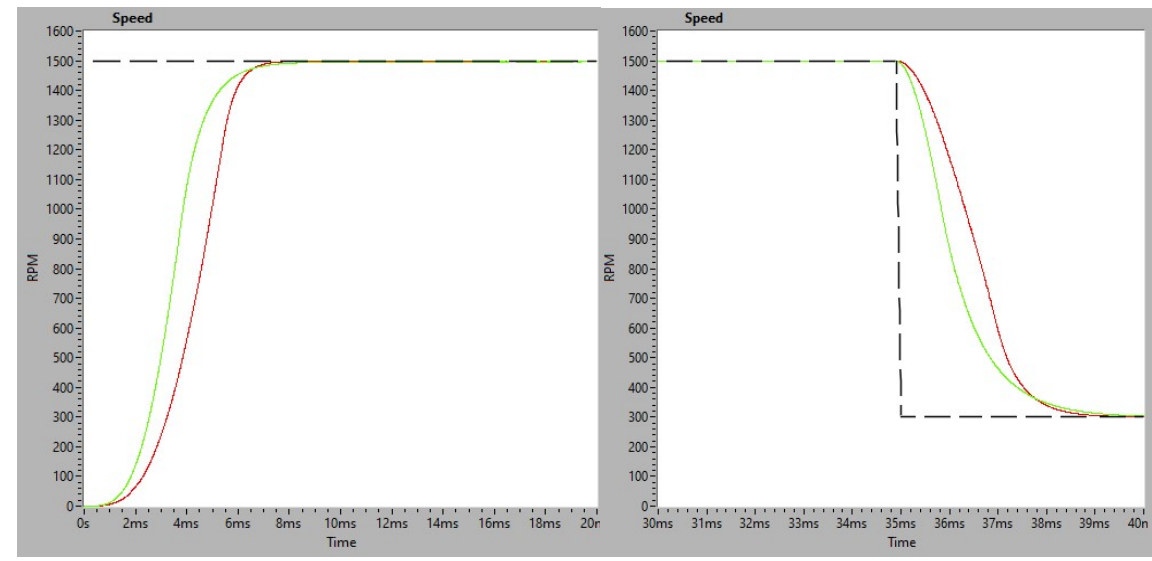

Gambar 9. Hasil Uji Beban Nol dengan Kecepatan 1500rpm

\subsection{Uji Beban Tetap dan Beban Berubah}

Beban tetap diberikan kemudian nilai kecepatan acuan diubah-ubah untuk melihat respon dinamis ketika beban tetap dengan kecepatan berubah. Beban tetap diberikan saat $\mathrm{t}=0 \mathrm{~ms}$ hingga $t=90 \mathrm{~ms}$. Selanjutnya diberi beban berubah pada $t=100 \mathrm{~ms}$ hingga $t=130 \mathrm{~s}$ untuk mengamati respon dinamis ketika diberi dan dilepas beban sistem secara tiba-tiba. Data kurva kecepatan yang ditampilkan pada pengujian ini adalah gabungan uji beban statis dengan kecepatan berubah-ubah pada 0ms - 90ms, kemudian tanpa beban 90ms - 100ms, lalu dibebani pada $100 \mathrm{~ms}-130 \mathrm{~ms}$, dan tanpa beban lagi dari 130ms - 140ms.

Uji pembebanan sangat diperlukan untuk menguji keandalan kendali yang didesain. Pengujian dilakukan pada kecepatan acuan yang sama seperti uji beban nol. Sedangkan untuk beban uji digunakan $9 \mathrm{Nm}$ karena perbedaan data hasil mulai bisa diamati pada beban ini. Gambar 10 
merupakan gambaran lengkap pengujian yang dilakukan pada penelitian ini, gambar yang disajikan adalah ketika uji kecepatan 1500rpm dan beban $9 \mathrm{Nm}$. Nilai PID Gain $I_{d}$ dan $I_{q}$ pada panel dibuat tetap nilainya karena bukan merupakan fokus dari penelitian ini.

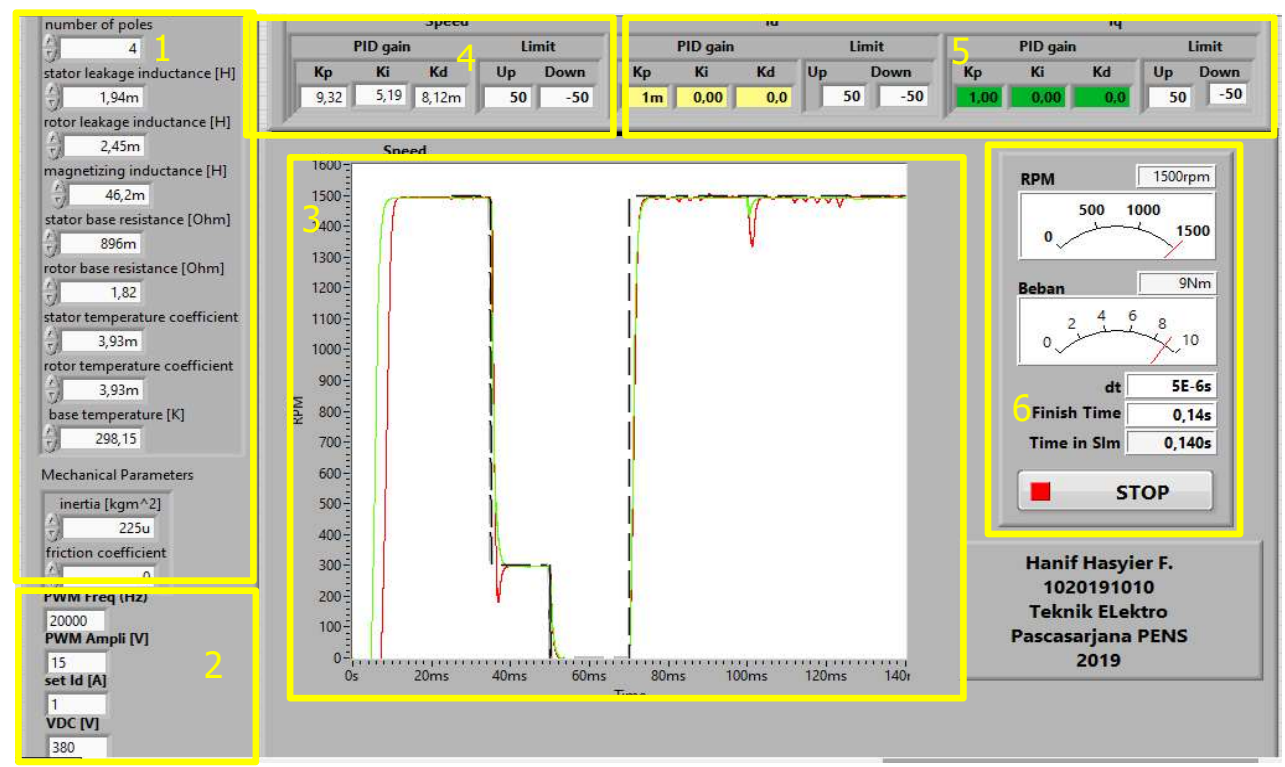

Gambar 10. Tampilan Panel Depan Pengujian di Labview

Kotak ke-1 pada Gambar 10 adalah parameter-parameter motor yang digunakan pada penelitian, terdapat parameter elektrik dan parameter mekanik. Parameter elektrik diperoleh dari uji motor induksi 3 fase yang meliputi uji hubung tegangan DC, uji tanpa beban, dan uji rotor tertahan. Sedangkan parameter mekanik bisa dilihat dari datasheet motor yang digunakan. Kotak ke-2 adalah spesifikasi inverter pada simulasi, pengaturan ini meliputi frekuensi carrier dan modulasi PWM, tegangan penyulut gate inverter, dan tegangan DC masukan inverter. Kotak ke-3 merupakan kendali kecepatan PID FOC. Ketika simulasi ANFIS dijalankan, nilai parameter PID inilah yang berubah-ubah. Kotak ke-4 merupakan $I_{d}$ Regulator dan $I_{q}$ Regulator. Pada penelitian ini hanya berfokus pada kendali kecepatan sehingga parameter PID pada $I_{d}$ dan $I_{q}$ Regulator dibuat tetap. Kotak ke-5 merupakan pengaturan kecepatan acuan, beban yang digunakan, dan panjang waktu simulasi.

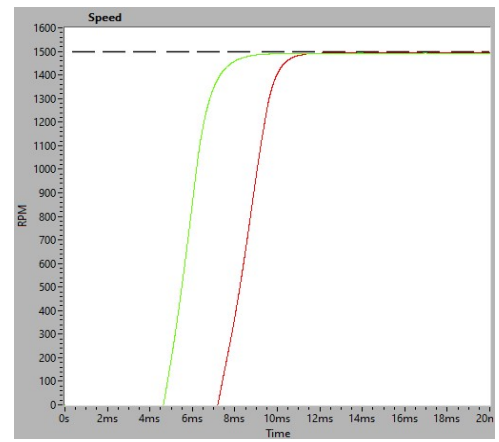

(a)

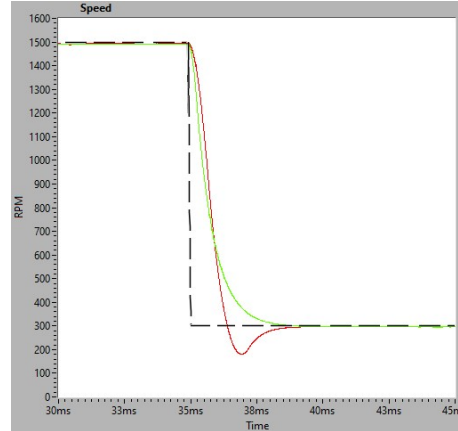

(b)

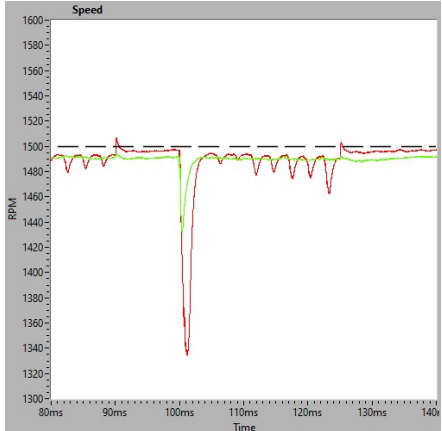

(c)

Gambar 11. Hasil Uji Beban Tetap dan Berubah dengan Kecepatan 1500rpm dan Beban $9 \mathrm{Nm}$ 
Pada beban saat diberi beban tetap, risetime dari PID-ANFIS lebih cepat hampir $2 x$ lipat. Begitu juga ketika kecepatan diturunkan, respon PID-ANFIS lebih cepat menyesuaikan acuan dibanding PID konvensional. Ketika uji kecepatan tinggi, PID konvensional memiliki undershoot ketika nilai kecepatan acuan diturunkan. Nilai undershoot pada pengujian ini mencapai $12 \%$. Gambar 11 (a) dan (b) merupakan respon naik dan respon turun dengan beban tetap pada kecepatan acuan 1500rpm dan beban 9Nm. Nilai undershoot terdapat pada Gambar 11 (b).

Tabel 4. Perbandingan Karakter Dinamis pada Uji Beban Tetap dan Berubah 9Nm

\begin{tabular}{|c|c|c|c|c|c|c|c|}
\hline \multirow{2}{*}{ Parameter } & \multicolumn{2}{|c|}{ 100rpm } & \multicolumn{2}{c|}{ 750rpm } & \multicolumn{2}{c|}{ 1500rpm } & \multirow{2}{*}{ Satuan } \\
\cline { 2 - 7 } & $\begin{array}{c}\text { Kendali } \\
\text { ANFIS }\end{array}$ & $\begin{array}{c}\text { Kendali } \\
\text { PID }\end{array}$ & $\begin{array}{c}\text { Kendali } \\
\text { ANFIS }\end{array}$ & $\begin{array}{c}\text { Kendali } \\
\text { PID }\end{array}$ & $\begin{array}{c}\text { Kendali } \\
\text { ANFIS }\end{array}$ & $\begin{array}{c}\text { Kendali } \\
\text { PID }\end{array}$ & \\
\hline Dead time & 4.9 & 7.4 & 4.6 & 7.2 & 4.6 & 7.2 & $\mathrm{~ms}$ \\
\hline Rise time & 6.0 & 8.0 & 6.0 & 8.0 & 6.5 & 9.0 & $\mathrm{~ms}$ \\
\hline Overshoot & 0.0 & 0.0 & 0.0 & 0.0 & 0.0 & 0.0 & $\%$ \\
\hline Undershoot & 0.0 & 0.0 & 0.0 & 0.0 & 0.0 & 12.0 & $\%$ \\
\hline Error steady & 2.0 & 2.0 & 0.4 & 0.3 & 0.6 & $0.6-$ osc & $\%$ \\
\hline Undershoot dibebani & 32.0 & 75.0 & 5.3 & 13.3 & 4.6 & 11.3 & $\%$ \\
\hline Overshoot dibebani & 12.0 & 35.0 & 0.0 & 1.3 & 0.0 & 0.6 & $\%$ \\
\hline Waktu recovery & 2.0 & 2.0 & 1.5 & 2.0 & 2.0 & 4.0 & $\mathrm{~ms}$ \\
\hline
\end{tabular}

Ketika uji beban berubah, PID-ANFIS memiliki overshoot dan undershoot dibebani yang nilainya jauh lebih kecil. Waktu recovery ketika diberi gangguan beban berubah relatif sama. Hal yang menarik adalah pada kecepatan tinggi terdapat osilasi kecil pada saat steady state PID konvensional, menunjukkan bahwa pada kecepatan tinggi kendali ini tidak memuaskan. Sedangkan kendali PID-ANFIS mampu menghilangkan osilasi pada saat itu. Hasil pengujian untuk kecepatan rendah dan sedang, tidak dijumpai osilasi saat steady state kendali PID konvensional. Gambar 11 (c) adalah hasil uji beban berubah dari kecepatan 1500rpm dan 9Nm beban. Ketika kecepatan 1500rpm dan beban penuh 9Nm, ANFIS secara adaptif menala PID menjadi $\mathrm{kp}=6.95, \mathrm{Ki}=5.14$, dan $\mathrm{Kd}=4.64 \mathrm{~m}$. Hasil PID-ANFIS pada pengujian beban berubah sangat memuaskan pada berbagai kecepatan dan beban. Tabel 4 merupakan perbandingan karakter dinamis keseluruhan pada pengujian beban penuh $9 \mathrm{Nm}$.

\section{KESIMPULAN}

Pada penelitian ini, telah dianalisis performa PID-ANFIS pada kendali kecepatan motor induksi 3 fase metode vektor-tidak langsung dengan parameter motor simulasi 2HP. Dataset ANFIS dari optimasi metode PSO mendapatkan hasil sesuai harapan dengan risetime selalu lebih cepat. Performa kendali telah diuji dengan kondisi beban tetap dan beban berubah, hasilnya PID-ANFIS jauh lebih baik dari PID konvensional khususnya pada kecepatan tinggi dan beban besar. PID-ANFIS pada penelitian ini unggul pada semua karakter dinamis. Dengan respon yang lebih cepat, kendali ini cocok digunakan pada plan yang membutuhkan percepatan tinggi seperti mobil listrik dan plan dengan kepresisian tinggi seperti printer, laser cutting, dll. Tantangan pada desain ANFIS adalah pencarian dataset yang terbaik. Dengan bantuan hardware SoC kedepannya, implementasi PID-ANFIS sangat memungkinkan untuk mendapat kendali kecepatan motor induksi 3 fase low-cost dengan peforma tinggi. 


\section{DAFTAR RUJUKAN}

Chao, C. T., Sutarna, N., Chiou, J. S., \& Wang, C. J. (2019). An optimal fuzzy PID controller design based on conventional PID control and nonlinear factors. Applied Sciences (Switzerland), 9(6), 1224-1242.

Fakhruddin, H. H., Toar, H., Purwanto, E., Oktavianto, H., Apriyanto, R. A. N., \& Aditya, A. W. (2020). Kendali Kecepatan Motor Induksi 3 Fase Berbasis Particle Swarm Optimization (PSO). ELKOMIKA: Jurnal Teknik Energi Elektrik, Teknik Telekomunikasi, \& Teknik Elektronika, 8(3), 477-492.

Ferdiansyah, I., Purwanto, E., \& Windarko, N. A. (2016). Fuzzy Gain Scheduling of PID (FGSPID) for Speed Control Three Phase Induction Motor Based on Indirect Field Oriented Control (IFOC). EMITTER International Journal of Engineering Technology, 4(2), 237-256.

Hannan, M. A., Ali, J. A., Mohamed, A., \& Hussain, A. (2018). Optimization techniques to enhance the performance of induction motor drives: A review. Renewable and Sustainable Energy Reviews, 81, 1611-1626.

Hussain, S., \& Bazaz, M. A. (2014). ANFIS implementation on a three phase vector controlled induction motor with efficiency optimisation. 2014 International Conference on Circuits, Systems, Communication and Information Technology Applications, CSCITA 2014, (pp. 391-396).

Menghal, P. M., \& Laxmi, A. J. (2016). Fuzzy Based Real Time Control of Induction Motor Drive. Procedia Computer Science, 85, 228-235.

Qudsi, O. A., Rosalina, I. I., \& Yanaratri, D. S. (2018). V / f SPWM Inverter for Single-phase Induction Motor Contrller Using Adaptive Neuro-Fuzzy Inference System. 2018 3rd International Conference on Information Technology, Information System and Electrical Engineering (ICITISEE), 158-163.

Rajab, S. (2019). Handling interpretability issues in ANFIS using rule base simplification and constrained learning. Fuzzy Sets and Systems, 368, 36-58.

Ridwan, R., Purwanto, E., Oktavianto, H., Rusli, M. R., \& Toar, H. (2019). Desain Kontrol Kecepatan Motor Induksi Tiga Fasa Menggunakan Fuzzy Pid Berbasis Idirect Field Oriented Control. Jurnal Integrasi, 11(2), 146-155.

Rind, S. J., Ren, Y., Hu, Y., Wang, J., \& Jiang, L. (2017). Configurations and Control of Traction Motors for Electric Vehicles: A Review. 3(3), 13-14.

Salim, \& Ohri, J. (2015). Fuzzy based PID controller for speed control of D.C. motor using LabVIEW. WSEAS Transactions on Systems and Control, 10, 154-159.

Sanjeevikumar, P., Daya, J. L. F., Wheeler, P., Blaabjerg, F., Fedák, V., \& Ojo, J. O. (2015). 
Wavelet transform with fuzzy tuning based indirect field oriented speed control of threephase induction motor drive. 2015 International Conference on Electrical Drives and Power Electronics, EDPE 2015 - Proceedings, September, (pp. 111-116).

Sathishkumar, H., \& Parthasarathy, S. S. (2017). A novel neuro-fuzzy controller for vector controlled induction motor drive. Energy Procedia, 138, 698-703.

Simon, R., \& Geetha, A. (2013). Comparison on the Performance of Induction Motor Control Using Fuzzy and ANFIS Controllers. ICECCN, (pp. 491-495).

Toar, H., Purwanto, E., Oktavianto, H., Ridwan, R., \& Rusli, M. R. (2020). Penala Parameter Pid Otomatis Pada Pengatur Kecepatan Motor Induksi Tiga Fasa. Jurnal Integrasi, 12(1), $1-12$. 